\title{
Questions of development and use of renewable energy sources for low power enterprises
}

\author{
Shuxrat Dungboyev ${ }^{* 1}$, Abdumalik Karimov², Nilufar Karshiyeva² \\ ${ }^{1}$ Tashkent State Technical University named after Islam Karimov, Department of "Electrical stations, networks and systems" of the \\ Electrical Energy Faculty, Tashkent, University St. 2A, 100095, Uzbekistan \\ ${ }^{2}$ Tashkent State Technical University named after Islam Karimov, Department of "Alternative energy sources" of the Electrical Energy \\ Faculty, Tashkent, University St. 2A, 100095, Uzbekistan
}

\begin{abstract}
Main problems of traditional and renewable energy development in the ecological context are considered in the article. The experience of developed industrial states in solving environmental problems and the work carried out in this direction in our country is presented. Today, many countries have a number of renewable energy targets: reducing greenhouse gas emissions, increasing the share of renewable energy sources in final energy consumption and meeting the growing demand for energy. Thus, the use of such sources of electricity as wind turbines, solar power plants or small hydroelectric power plants in the minimum configuration, which includes only an energy converter (wind turbine with a PVC generator or a hydraulic turbine with a generator) and a device for converting electric current parameters to standard values (inverter, stabilizer), not in able to provide high-quality and guaranteed constant power supply to the consumer.
\end{abstract}

\section{Introduction}

Increasing energy efficiency and the need for resource conservation are actual problems in almost all countries around the world. To solve these problems, a new energy policy has been developed in recent years based on the use of hybrid energy systems with renewable energy sources (HRES - Hybrid Renewable Energy System), in which traditional sources of electricity are combined with renewable ones (such as solar panels, wind generators, etc.) [1-8].

The existing hybrid energy systems and control algorithms do not fully meet the efficiency requirements for a number of reasons. Firstly, the cost of electricity generated by various suppliers (electricity sources) is not taken into account; secondly, if electricity generated by renewable energy sources is not enough for consumers, then external power grids are used without taking into account the electricity tariff plan and often at a disadvantageous price.

On October 3, 2018, the President of the Republic of Uzbekistan Shavkat Mirziyoyev held a meeting devoted to an in-depth analysis of the state of affairs in the electric power industry, the definition of additional measures for the development of the industry [9-10].

It was noted at the meeting that the use of modern technologies in the creation of new power generating capacities, the widespread introduction of renewable energy sources should become the main tasks of JSC "Uzbekenergo".

\section{Half-wave circuit}

Our sunny Uzbekistan is just starting to develop a strategy for the development of renewable energy sources [11-14]. Although the current costs of renewable energy technologies significantly exceed the costs of traditional technologies for generating energy, it is already possible to outline obvious targets for their implementation.

For Uzbekistan, these are, first of all, installations for generating electricity and heat at low-power facilities of the local industry and the construction sector, facilities in the agricultural and social spheres, farms, greenhouse farms, etc.

The main share of this potential is solar energy, its total potential is 51 billion toe, and the technical potential is 177 million toe. The technical potential of solar energy is almost four times higher than the primary energy consumption in the country. The favorable climatic and geographical position of the country allows the wide use of the potential of solar energy for industrial purposes. The total potential of wind energy is 2.2 million toe. There is a possibility of technical development of $19 \%$ of it. The total potential of geothermal energy is greater than the potential of solar energy and amounts to 67 billion toe. Due to the underdevelopment of simple and cost-effective technologies for the development of this type of energy, there is a possibility of technical development only equal

\footnotetext{
* Corresponding author: elyor.saitov@mail.ru
} 
to 0.3 million toe. parts. Table 1. Shown renewable energy potential in Uzbekistan.

Table 1.

\begin{tabular}{|l|l|l|l|}
\hline № & $\begin{array}{l}\text { Renewable energy } \\
\text { sources }\end{array}$ & Gross potential & $\begin{array}{l}\text { Technical } \\
\text { potential }\end{array}$ \\
\hline 1. & Hydropower & 9.2 million toe & 2 million toe \\
\hline 2. & Wind power & 2.2 million toe & 0.4 million toe \\
\hline 3. & Solar energy & $50973 \mathrm{M}$ toe & 177 million toe \\
\hline 4. & Geothermal energy & $\begin{array}{l}67,000 \text { million } \\
\text { toe }\end{array}$ & 0.3 million toe \\
\hline 5. & $\begin{array}{l}\text { Common } \\
\text { alternative energy } \\
\text { sources }\end{array}$ & $\begin{array}{l}117,984 \text { million } \\
\text { toe }\end{array}$ & 179.3 million toe \\
\hline
\end{tabular}

Today, the share of renewable energy sources (RES) in world energy consumption is $19.3 \%$, fossil fuel and energy resources $-78.4 \%$ and nuclear energy $-2.3 \%$. The global share of renewable energy sources in electricity production in 2018 was $26 \%$. The total capacity of renewable energy sources in our country amounted to $1,844 \mathrm{MW}$ in 2018, which is about $3 \%$ of the total energy consumption of this type of energy. On average, $10-12 \%$ of the total amount of electricity is generated on the basis of renewable energy sources.

Today, the use of renewable energy sources in remote and inaccessible areas located in mountainous and semi-desert zones, as well as in remote pastures, is quite competitive in relation to traditional energy sources.

According to the publication, prepared by the UNDP office in Uzbekistan, it gives a fairly complete overview of the current state of energy use in the country and the possibilities of using renewable energy sources not only from a technical, but also, which is very important, from an economic and social point of view [15-18].

Thus, the task of substantiating the feasibility of establishing power generating complexes on the territory of Uzbekistan that convert the energy of wind, solar radiation and water flow is undoubtedly relevant, and the scientific and practical significance of issues related to the development of methods for calculating their parameters is beyond doubt [19, 20].

The authorities are considering the development of solar and wind energy as part of the transition to renewable sources. These industries are poorly represented in Uzbekistan today.

By 2025, the share of solar energy in generated capacity should grow to $2.3 \%$, and wind energy - to $1.6 \%$, if the plan works. The only solar power plant in Uzbekistan operates in the Namangan region. Construction of the first Uzbek wind farm in the Tashkent region is still underway.

Analysis of literature sources allows us to determine the following main areas of research in the field of wind energy:

- calculation of wind power depending on its speed, height and terrain profile;

- determination of wind speed depending on the geographical position of the wind turbine;

- designs and features of wind turbines;

- economic efficiency.
The formula for calculating the power of a wind turbine (W), which includes a wind wheel, a gearbox and a generator, has the form [21]:

$$
\mathrm{P}=0.5 \mathrm{p} .5 \mathrm{~V}^{3} \mathrm{C}_{\mathrm{p}} n_{\Gamma} n_{\mathrm{p}},(1)
$$

where $\rho$ is the air density, $\mathrm{kg} / \mathrm{m}^{3}$;

$\mathrm{S}$ - area swept by the wind wheel, $\mathrm{m}^{2}$;

$\mathrm{C}_{\mathrm{p}}$ - power utilization factor (determined by the wind wheel design);

$n_{\Gamma} n_{\mathrm{p}}$ - generator and gearbox efficiency.

To determine the energy characteristic of a stationary wind flow (specific power, $\mathrm{W} / \mathrm{m}^{2}$ ), the following expression is used:

$$
\mathrm{P}_{\text {уд }}=0.5 \mathrm{pV}^{3}(2)
$$

The specific power of the wind flow (2), in contrast to the power of the wind turbine (1), does not depend on the method of converting wind energy. Its value is determined only by the wind speed and air density, that is, the geographic location and installation height of the wind turbine.

In expressions (1) and (2), the wind speed, even at a given point of the terrain, is a random value. Its calculation is carried out by creating a probabilistic description of the random process of changing the wind speed at a given time interval by dividing it into time intervals, within which the wind speed is considered constant [22-25].

The measurement of wind speed in this area is constantly carried out at meteorological stations. However, the purely mechanical transfer of the values measured at the meteorological station to a given point of the terrain where this meteorological station is located cannot be considered legitimate, since the measurement result depends on the relief and landscape characteristics of the terrain and the height of the measurements. The relationship between the wind speed reduced to a specific location and the wind speed measured at the meteorological station is determined by the relation [26]:

$$
V_{\text {пр }}=\frac{K_{0}}{K_{\Phi}} V,
$$

where $K_{0}-$ coefficient of openness according to Milevsky classification;

$K_{\Phi}$ - coefficient that takes into account the actual openness of the area.

The dependence of the speed on the height is determined by the known relation:

$$
V_{1}=V_{0}\left(\frac{h_{1}}{h_{0}}\right)^{k}(3)
$$

In expression (3), the wind speed $V_{0}$ at the height of the weather vane $h_{0}$, at the height of the rotor axis $h_{1}, \mathrm{k}-$ coefficient, the approximate value of which is $0.14-0.2$. Various sources offer different methods for determining the coefficient $\mathrm{k}$ depending on the characteristics of the terrain [27], wind speed [28].

\section{Full waive circuit}

The amount of solar energy entering the Earth is simply enormous and significantly exceeds the energy of all the world's carbon fuels. Simple calculations show that only $0.0125 \%$ of its volume could meet all of today's global energy needs. 
Solar energy is used mainly in two ways - in the form of thermal energy, through the use of various thermal systems, and through photochemical reactions (photovoltaic) [29]. The last method is the direct conversion of solar radiation and electrical energy using solar panels. Photovoltaic cells of solar cells are lightsensitive plates made of semiconducting material: selenium, silicon, gallium arsenide, silicon diselenide, etc. Solar panels can be of various capacities - from portable installations of several watts to multi-watt power plants covering millions of square meters.

The process of converting solar radiation into electrical energy is carried out at solar power plants (SPP) [30]. SPP is one of the most promising and fastest growing areas for the use of renewable energy sources.

Depending on the material, design and production method, there are three generations of photovoltaic converters (PVC):

- PVC of the first generation based on crystalline silicon wafers. According to the manufacturing method, polycrystalline and monocrystalline silicon wafers are distinguished. At present, PVCs of the first generation are most widely used due to their low cost;

- PVCs of the second generation based on thin films, allow the manufacture of flexible, and, in the future, cheaper, PVCs of a large area, but with a lower conversion coefficient in comparison with the PVCs of the first generation;

- PVC of the third generation based on organic and non-organic materials is currently at the research stage.

In the general case, PVCs that are part of the SPP can have a fixed or tracking photo detector without a concentrator or with a concentrator of solar radiation.

Various options for concentrators and tracking systems, differing in technical and economic indicators and efficiency are known. However, it is impossible to unequivocally determine any option for constructing a SPP as the best, without conducting appropriate research. Power $P(\mathrm{~kW})$ generated by the SPP can be calculated by the formula [31-38]:

$$
\mathrm{P}=\mathrm{R}_{\Sigma} S_{\eta},(4)
$$

where R- current total power of solar radiation (direct, reflected and scattered) in the focusing plane, $\mathrm{kW} / \mathrm{m}^{2}$;

$\mathrm{S}-$ area of all PVC, $\mathrm{m}^{2}$;

$\eta$ - efficiency PVC.

In formulas (4), the parameter $\eta$ determines the ability of the PVC to convert the energy of solar radiation into electrical energy. Its value depends on many factors, including the material, design and production method of the PVC, temperatures and light transmission of the protective coating. The value of $\mathrm{R}$ is determined by the territorial location of the SPP, climatic conditions at a given time, terrain, date and time of day, the presence of a tracking system, a concentrator and their design parameters. In some works, the $\mathrm{R}$ component associated with the presence and design of tracking systems and concentrators is taken into account as a separate coefficient or as a component of the solar battery efficiency.
According to the forecast, the production of electricity in Uzbekistan for 2019-2025 will increase by $40 \%$ by 2025 , compared to 2018 , and will reach 84.9 billion kilowatt-hours. It is planned to increase the existing electricity production capacity by 2.5 times, which will allow doubling the annual electricity production by 2030 . Fig. 1. Shown forecast of electricity production in Uzbekistan until 2025 (billion $\mathrm{kWh}$ ).

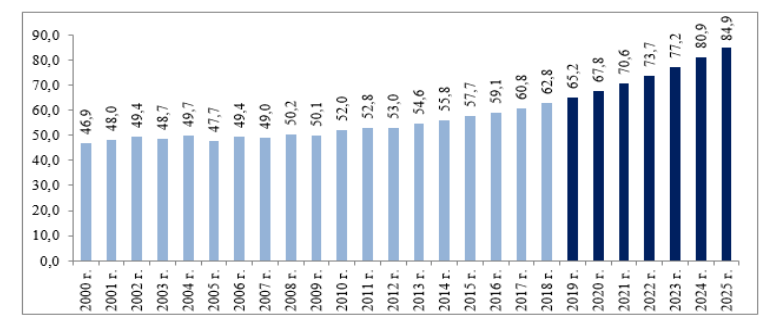

Fig.1. Forecast of electricity production in Uzbekistan until 2025 (billion $\mathrm{kWh}$ ).

Today, many countries have a number of renewable energy targets: reducing greenhouse gas emissions, increasing the share of renewable energy sources in final energy consumption and meeting the growing demand for energy. Uzbekistan is also developing a number of goals to promote this sector and increase this share of energy in the overall energy balance. In particular, below are the target parameters for the further development of renewable energy: by 2025, it is planned to increase the share of renewable energy sources in electricity production from $10-12 \%$ in 2018 to $20 \%$, including hydroelectric power plants - from $10-12 \%$ to $15,8 \%$, solar energy $-2.3 \%$ and wind energy $-1.6 \%$.

\section{Conclusion}

The method for calculating the economic efficiency of converting solar radiation into electricity is similar to the method used to calculate the economic efficiency of wind power plants. The decisive role is played by the total capital investment $(\mathrm{K})$ and the total annual operating costs (C), which depend on the type of solar panels, their design, the availability and design of control systems.

The solution to the problem is the use of power complexes or hybrid power systems (EC) for the power supply of an autonomous consumer (low-power enterprises) using wind, sun and water flow of small rivers as primary energy. Due to the availability of renewable energy sources in Uzbekistan, which do not have a negative impact on the environment, interest in the use of these types of energy will grow in the near future. An increase in the use of renewable energy sources in all sectors of the economy will help, in the face of GDP and population growth in the country, reduce the growing demand for fossil fuel and energy resources, reduce our country's dependence on imported energy resources, allow supplying energy resources for new sectors of the economy, and reduce emissions in atmosphere of $\mathrm{CO}_{2}$ and other harmful substances, as a result of which the effects of climate change will be mitigated. 
Thus, the use of such sources of electricity as wind turbines, solar power plants or small hydroelectric power plants in the minimum configuration, which includes only an energy converter (wind turbine with a PVC generator or a hydraulic turbine with a generator) and a device for converting electric current parameters to standard values (inverter, stabilizer), not in able to provide high-quality and guaranteed constant power supply to the consumer.

\section{References}

1. Finlay Colville. How Buried Contacts Brought Lasers to Life in Solar/ Production\&inspection productiontechnology USA, pp. 74-77, 2009.

2. Chen Jiahe, Emanuele Cornagliotti, Eddy Simoen, Ellen Hieckmann, Joerg Weber and Jef Poortmans, "Adeeplevel transient spectroscopy study on the in terfacestates across grain boundaries in multicrystalline silicon" physica status solidi (RRL)-Rapid Research Letters 5, no. 8 (2011): 277-279.

3. M.K.Bakhadyrkhanov, S.A.Valiev, N.F.Zikrillaev, S.V.Koveshnikov, E.B.Saitov, S.A.Tachilin. Silicon photovoltaic cells with clusters of nickel atoms. Applied solar energy 52 (4), pp.278-281, 2016.

4. Sh.A.Faiziev and Yu.B.Sobirov. Measurements of Solar Resources in Uzbekistan // Applied Solar Energy, 2017, Vol. 53, No. 1, pp. 57-60.

5. Javoxir Toshov., Elyor Saitov. Portable autonomous solar power plant for individual use. E3S Web of Conferences 139 01087. 2019.

6. https://kun.uz/ru/news/2020/06/09/masdarpostroit-v-uzbekistane-odnu-iz-samyx-bolshixvetryanyx-elektrostansiy-v-mire

7. Shavkat Fayziev, Yuldash Sobirov, Sirojiddin Makhmudov. Measurement of the Direct Flux of Solar Radiation During Operation of a Big Solar Furnace // International Journal of Sustainable and Green Energy 2018; 7(4): 2128

http://www.sciencepublishinggroup.com/j/ijsge doi: $10.11648 /$ j.ijrse.20180704.11

8. I.Sapaev, E.Saitov, N.Zoxidov and B.Kamanov. Matlab-model of a solar photovoltaic station integrated with a local electrical network. Conmechydro - 2020 IOP Conf. Series: Materials Science and Engineering 883(2020) 012116.

9. Krivtsov V. S., Oleynikov a.m. et al. Inexhaustible energy. Book 1. Wind Power Generators// Textbook. Kharkiv: NATs.Aerocom. UN.-t "Kharkiv aviation. Inst.", Sevastopol: Sevast. NATs. tehn. Univ., 2003. $-400 \mathrm{p}$.

10. Krivtsov V. S., Oleynikov a.m. et al. Inexhaustible energy. KN.2. Wind power// Textbook. Kharkiv: NATs.Aerocom. UN.-t
"Kharkiv aviation. Inst.", Sevastopol: Sevast. NATs. tehn. Univ., 2004. -519 p.

11. Derzky V. G. Analytical forecast of world wind power development /Derzky V. G. //Power engineering and electrification-2010. - no. 1. P. 53-56.

12. Tadzhiev U. A., Kiseleva E. I., tadzhiev M. U., Zahidov R. A. Features of formation of wind flows over the territory of Uzbekistan and the possibility of their use for power generation. Part I.// Solar Energy Equipment. 2014. No. 3. S. 46-52.

13. Community R. A., Kremkow V. M. the wind energy Potential of Uzbekistan// Solar technology. 2015. no. 4. Pp. 106-107.

14. Community R. A., Kremkow V. M. the wind energy Potential of Uzbekistan// Solar technology. 2015. no. 4. Pp. 106-107.

15. Zavarina M. V. Calculated wind speeds at the heights of the lower layer of the atmosphere. L.: Hydrometeoizdat, 1971. - 162 p.

16. Shoguchkarov S.Q., Jamolov T.R., Mukhtarov N.Y., Yuldoshev I.A. Study of the Operating Parameters of a Wind Power Plant with 0,75 MW Power under the Conditions of Tashkent Oblast Applied Solar Energy.2018. Vol.54, pp. 392-394.

17. M.K.Bakhadyrkhanov., S.A.Valiev., N.F.Zikrillaev., S.V.Koveshnikov., E.B.Saitov., S.A.Tachilin. Silicon-based solar cells with clusters of nickel atoms // Geliotekhnika No. 4 pp. 28-32, 2016.

18. М.К.Бахадырханов., С.А.Валиев., Н.Ф.Зикриллаев., С.В.Ковешников., Э.Б.Саитов., С.А.Тачилин. Фотоэлементы на основе кремния с кластерами атомов никеля. // Гелиотехника №4 2016 г. Стр.28-32.

19. E.B.Saitov. Study of Quantitative and Qualitative Characteristics of Nickel Clusters and Semiconductor Structures. Journal of Materials Science and Chemical Engineering. №4 y. 2016, pp. 30-35.

20. Abdurakhmanov B.A., Bakhadirkhanov M.K., Ayupov K.S., Iliyev H.M., Mavlyanov A., Saitov E.B., Kamalov H.U. Formation of Clusters of Impurity Atoms of Nickel in Silicon and Controlling Their Parameters. Nanoscience and Nanotechnology, Vol. 4, No. 2, 2014. pp. 23-26.

21. Зикриллаев Н.Ф., Саитов Э.Б. Фотоэлементы на основе кремния с микробарьерами Шоттки. Вестник Туринского политехнического университет; 2014. С. 3133.

22. Саитов Э.Б. Исследование кремниевых фотоэлементов c микрогетероструктурами. Спец выпуск //Вестник ТашГТУ, 2015.С.66-71. 
23. Илиев Х.М., Саитов Э.Б., Сайдалиев С.Х., Тачилин С.А. Переносная автономная солнечная электростанция индивидуального использования. Проблемы энерго- и ресурсосбережения. ТашГТУ, 2014, №1-2. с. 183-185.

24. Зикриллаев Н.Ф, Саитов Э.Б., Тухтасинов M.M. Низкотемпературная диффузия примесей $\mathrm{Ge}, \mathrm{S}, \mathrm{Ni}$ и $\mathrm{Mn}$ в кремнии для получения фотоэлементов. Вестник Туринского политехнического университета, 2014. c. 34-39.

25. Зикриллаев Н.Ф., Саитов Э.Б., Тачилин С.А. Эффективные инверторы для альтернативных источников энергии. Международная научно-практическая конференция «Проблемы современного машиностроения». Андижан 16-17 мая 2013 года. С.16-18.

26. Бахадырханов М.К. Абдурахмонов Б.А, Саитов Э.Б. Исследование вольт-амперной характеристики микроструктуры кластеров атомов никель-кремний. Академия наук Республики Узбекистан. Фундаментальное и прикладной вопроси физики. Труди международный конференции посвященной 70-летю физика техника институт НПО «Физика-сонца»:. 14 - 15 ноября 2013 г. Ташкент, с. 107-108.

27. M.K.Bakhadyrkhanov, S.A.Valiev, N.F.Zikrillaev, S.V.Koveshnikov, E.B.Saitov., S. A.Tachilin. Silicon Photovoltaic Cells with Clusters of Nickel Atoms. Applied Solar Energy, 2016, Vol. 52, No. 4, pp. 278-281.

28. B.A.Abdurakhmanov, M.K.Bakhadirkhanov, H.M.Iliyev, S.B.Isamov, A.Mavlyanov, E.B.Saitov, H.U.Kamalov, Z.Saparniyazova, O.Sattarov, U.Kh.Sodikov, N.F.Zikrillayev. Silicon with Clusters of Impurity Atoms as a Novel Material for Photovoltaics. Nanoscience and Nanotechnology 2014, 4(3): 41-43.

29. М.К.Бахадирханов,

С.А.Валиев, Н.Ф.Зикриллаев, С.В.Ковешников, Э.Б.Саитов, С.А.Тачилин. Фотоэлементы на основе кремния с кластерами атомов никеля. Журнал Гелиотехника, Академия наук республика Узбекистан, №4, 28-32 ст.

30. Javoxir Toshov., Elyor Saitov. Portable autonomous solar power plant for individual use. E3S Web of Conferences 139 01087. 2019.

31. E.B.Saitov. Technology of manufacturing solar cells with clusters of $\mathrm{Ni}$ atoms. Asian journal of multidimensional research impact factor, ISSN: 2278-4853 Vol 8, Issue 3, March 2019=6.053, pp. 494-499.

32. Zikrillayev Nurilla, Saitov Elyor, Botirov Bozorbek, Nasirdinov Bakhodirw, Kurbanov Yunus, Turayev Farxodjon, Shodiyeva Nozina. Study of the results of diffusion doping technique for producing heterostructures (Si$\mathrm{Ge)}$ using microprobe analysis. Austrian Journal of Technical and Natural Sciences. «East West» Association for Advanced Studies and Higher Education GmbH. No.1-2. pp.5661, 2019.

33. I.Sapaev, E.Saitov, N.Zoxidov and B.Kamanov. Matlab-model of a solar photovoltaic station integrated with a local electrical network. Conmechydro - 2020 IOP Conf. Series: Materials Science and Engineering 883(2020) 012116.

34. Saitov E.B, Toshov J.B, Umarov Sh.B., Fayzullayev B.H., Abdullabekov I.A, NasriddinovB.A. Optimization of Solar Power Systems in Different Regions. Journal of critical reviews, ISSN - 2394-5125VOL 7, ISSUE 15, 2020.

35. Saitov Elyor Bakhriddinovich, Pulatov Abror Obidovich. Development of an Experiment Control System at a Laboratory Installation of a Photovoltaic Station in a Remote access Mode Based on Web Technologies. Journal of critical reviews, ISSN - 2394-5125 VOL 7, ISSUE 15, 2020.

36. Zikrillayev Nurullo, Saitov Elyor. Silicon materials -the future of photovoltaics. Monograph - LAP LAMBERT Academic Publishing. 2019, ISBN: 987-620-0-50311-4.

37. Javoxir Toshov., Elyor Saitov. Portable autonomous solar power plant for individual use. E3S Web of Conferences 139 01087. 2019.

38. I Sapaev, E Saitov, N Zoxidov, B Kamanov. Matlab-model of a solar photovoltaic station integrated with a local electrical network. IOP Conference Series: Materials Science and Engineering, 883, 1, 012116, IOP Publishing, 2020/7/1. 